\title{
Pengaruh Model Pembelajaran Example Non Example berbantuan Poster Comment Terhadap Pemahaman Konsep Matematis
}

\author{
Doni Sabroni1 ${ }^{1)}$, Budi Koestoro2), Asmiati3)
}

1), 2),3) Universitas Lampung, Indonesia

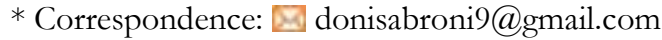

\begin{tabular}{|c|c|}
\hline Article Info & Abstract \\
\hline $\begin{array}{l}\text { Article History } \\
\text { Received : 29-09-2018 } \\
\text { Revised : 15-10-2018 } \\
\text { Accepted : 28-11-2018 }\end{array}$ & $\begin{array}{l}\text { This research has a purpose to know whether there is influence of the use of } \\
\text { learning model Example Non Example assisted Poster Comment to the } \\
\text { comprehension ability of mathematical concept. This research type } \\
\text { is keyexperimental design, this research population is all students of class VII }\end{array}$ \\
\hline $\begin{array}{l}\text { Keywords: } \\
\text { Example non example; } \\
\text { Poster comment; } \\
\text { Understanding } \\
\text { mathematical concept. }\end{array}$ & $\begin{array}{l}\text { Madrasah Tsanawiyah (MTs) Al-Hidayah Srikuncoro academic year 2016/2017. } \\
\text { In this research, the data analysis used is by using variance analysis (anova) one } \\
\text { cell road is not same. The result of this research is that there is influence of } \\
\text { learning model of Example Non Example with Poster Comment with the ability } \\
\text { of understanding mathematical concepts, which the application of learning model } \\
\text { Example Non Example with Poster Comment gives better concept of } \\
\text { mathematics concept compared with the application of conventional model } \\
\text { supported by Poster Comment and also the application of learning model } \\
\text { Example Non Example with Poster Comment provides better mathematical } \\
\text { concept capability compared to conventional learning model, and conventional } \\
\text { teaching model application provides mathematical concept capability similar to } \\
\text { conventional modeled learning application with poster comment. }\end{array}$ \\
\hline
\end{tabular}

\section{PENDAHULUAN}

Kemampuan pemahaman konsep matematis sangat penting untuk dimiliki bagi siswa, karena konsep matematika yang satu dengan yang lain saling berkaitan sehingga untuk mempelajarinya harus runtun dan berkesinambungan [1][3]. Namun kenyataannya kemampuan pemahanan konsep siswa masih belum menggembirakan. Kondisi ini didukung oleh hasil observasi peneliti ke beberapa SMPN di Kabupaten Sukadana, ditemukan bahwa 76\% siswa masih memiliki kemampuan pemahaman konsep yang rendah.

Kurangnya pemahaman konsep matematika siswa ini, dipengaruhi oleh kurang fokusnya siswa dalam belajar. Sebagian siswa hanya menghafal rumus tanpa alur penyelesaian atau rumus awal yang dijadikan dasar dari permasalahan yang diberikan. Terlebih lagi jika mereka diberikan soal dengan sedikit variasi yang membutuhkan penalaran lebih, hanya beberapa siswa yang mampu menjawab dengan benar, itupun siswa yang tergolong lebih pandai dari siswa yang lain dikelasnya. Permasalahan ini disebabkan oleh model pembelajaran yang kurang tepat dalam pembelajaran matematika. Hal ini didukung oleh penelitian yang mendapatkan kurangnya hasil pemahaman konsep karena monotonnya model pembelajaran yang digunakan dan soal-soal yang diberikan guru pada saat proses pembelajaran. Sehingga bisa dikatakan bahwa penggunaan model pembelajaran yang tepat dapat memberikan pengaruh pada tingginya hasil pemahaman konsep siswa. Dalam hal ini penulis melihat dibutuhkannya model pembelajaran yang tepat untuk mempelajari definisi suatu konsep-konsep dalam matematika. Salah satu model pembelajaran yang dapat digunakan adalah model pembelajaran Example Non Example yang diharapkan mampu memperbaiki masalah kemampuan pemahaman konsep siswa. 
Model pembelajaran examples non examples mendorong siswa untuk belajar lebih kritis dengan jalan memecahkan permasalahan-permasalahan yang terkandung dalam contoh-contoh gambar yang disediakan. Penggunaan model pembelajaran examples non examples lebih mengutamakan konteks analisis siswa, karena konsep yang diajarkan diperoleh dari hasil penemuan dan bukan berdasarkan konsep yang terdapat dalam buku. Model pembelajaran Example Non Example memiliki tujuan supaya siswa mampu mengklasifikasikan suatu konsep yang dipelajari dengan pemikirannya sendiri dengan menggunakan example atau memberikan gambaran dari materi yang dipelajari dan non-example atau memberikan gambaran yang bukanlah contoh dari materi yang dipelajari. Model pembelajaran ini diharapkan dapat menjadi alternatif terhadap model pembelajaran kelas konvensional dan pembelajaran ini bertujuan agar para siswa saling membantu dalam kelompok-kelompoknya. Hasil dari beberapa penelitian menunjukkan bahwa model pembelajaran Example Non Example memiliki efek yang baik terhadap keaktifan siswa [10], hasil belajar pelajaran biologi [11], dan hasil belajar matematika siswa.

Mufidah berpendapat bahwa penggunaan media yang dapat digunakan dalam metode Example Non Example salah satunya adalah media gambar yang berhubungan dengan kompetensi dasar yang terdapat dalam kurikulum satuan pendididkan sekolah menengah kejuruan. Metode poster coment diduga salah satu metode yang cocok disinergikan dalam model Example non Example. Penulis akan menerapkan model pembelajaran Example Non Example berbantuan bengan metode Poster Comment agar penyampaian materi dengan tujuan memperbaiki kemampuan pemahaman konsep matematis siswa sekaligus agar membedakan dengan penelitian-penelitian yang sebelumnya.

Metode Poster Comment merupakan salah satu metode yang melibatkan semua siswa agar dapat mengikuti pembelajaran secara aktif, untuk memotivasi serta dapat memberikan pengalaman belajar yang aktif dan kreatif [14]. Metode Poster Comment yang mana metode ini adalah metode pembelajaran dengan penyajian bahan pembelajaran dengan menggunakan poster. Para guru memanfaatkan metode pembelajaran Poster Comment ini untuk mengajak para siswa agar dapat memunculkan pendapat dari suatu poster, yang mana poster tersebut memiliki keterkaitan dengan pencapaian kompetensi materi pada pembelajaran tersebut. Metode Poster Comment mampu meningkatkan berfikir kreatif. Selain itu penelitian lain mengungkapkan bahwa metode Poster Comment mampu meningkatkan keaktifan belajar, berpikir kritis serta memusatkan perhatian siswa dalam berlangsungnya belajar di dalam kelas [16].

Berdasarkan uraian yang telah dijelaskan diatas maka penulis tertarik melakukan sebuah penelitian dengan judul Pengaruh Model Pembelajaran Example Non Example Berbantuan Poster Comment Terhadap Pemahaman Konsep Matematis.

\section{METODE PENELITIAN}

Dalam penelitian ini, penulis menggunakan metode penelitiankuantitatif. Jenis penelitian yang digunakan yaitu penelitian eksperimen. Jenis eksperimen yang digunakan merupakan Quasy-Experimental. Penelitian yang akan peneliti lakukan adalah responden dikelompokkan menjadi dua kelompok yaitu kelas eksperimen dan kelas kontrol. Kelas eksperimen diberi perlakuan model pembelajaran Example Non Example berbantuan Poster Commentdan kelas control diberi perlakuan metode konvensional. Waktu penelitian ini dilakukan saat semester genap pada tahun ajaran 2017/2018. Sampel yang terpilih adalah peserta SMPN 1 Sukadana, Lampung Timur tahun ajaran 2017-2018 kelas VIIA (ekaperimen) dan VIIC (control). Variabel bebas dalam penelitian ini ialah metode pembelajaran Example Non Example berbantuan Poster Comment, sedangkan variabel terikatpada penelitian ialah pemahaman konsep matematis. Teknik pengumpulan data yang digunakan ialah observasi, wawancara, tes, dan dokumentasi. Data penelitian ini divalidkan dengan validitas isi dan juga validitas konstruk [17]. Teknik 
analisis data dalam penelitian ini uji t, namun sebelum uji t, dilakukan uji normalitas dan homogenitas terlebih dahulu.

\section{HASIL DAN PEMBAHASAN}

Hasil penelitian ini ialah terdapat pengaruh model pembelajaran Example Non Example berbantuan Poster Comment terhadap pemahaman konsep matematis siswa. Setelah proses pembelajaran telah usai, selanjutnya dilakukan pengambilan data. Setelah data dari semua variabel terkumpul selanjutnya data digunakan untuk pengujian hipotesis.

Dari penelian tersebut terlihat bahwa hasil tes yang diberikan kepada kelas eksperimen dengan model pembelajaran Example Non Example berbantuan Poster Comment memperoleh nilai tertinggi 90 serta nilai terendah 50. Selanjutnya, hasil tes yang diberikan kepada kelas kontrol dengan metode pembelajaran konvensional memperoleh nilai tertinggi 80 serta nilai terendah 50, selanjutnya dilakukan uji normalitas untuk mengetahui sebaran pada kelas tersebut berdistribusi normal atau tidak. Uji normalitas menggunakan metode Liliefors.

Hasil uji normalitas yang diperoleh tampak bahwa taraf signifikan 5\% dari $L_{\text {observasi }}$ untuk kelas eksperimen yaitu 0,140 kurang dari $L_{0,05}$ yaitu 0,193 sehingga hipotesis nol diterima jadi data pada kelas eksperimen normal. $L_{\text {observasi }}$ untuk kelas kontrol yaitu 0,112 kurang dari $L_{0,05}$ yaitu 0,193 sehingga hipotesis nol diterima jadi data pada kelas kontrol normal.

Dari uji homogenitas didapat bahwa nilai $x^{2}$ biturg $<x^{2}$ tabel dengan hal ini dapat disimpulkan bahwa $H_{0}$ diterima atau sampel berasal dari populasi yang memiliki varians sama. Setelah diketahui data berasal dari populasi yang berdistribusi normal dan populasi yang sama (data homogen), maka dilanjutkan uji hipotesis dengan menggunakan uji-t. Dilakukannya pengujian hipotesis ini guna mengetahui ada atau tidaknya pengaruh dari perlakuan penerapan model pembelajaran terhadap kemampuan pemahaman konsep matematis.

Berdasarkan perhitungan, didapat bahwa $T_{\text {bitung }}=5,228>T_{\text {tabel }}=2,713$ ini berarti pada taraf signifikasi $a=0,05 H_{0}$ Ditolak. Dengan demikian dapat disimpulkan bahwamodel pembelajaran Example Non Example dan metode Poster Comentberpengaruh terhadap rata-rata pemahaman konsep matematis. Selanjutnya kemampuan pemahaman konsep matematis peserta didik dengan perlakuan model model pemebelajaran Example Non Example dan metode Poster Comentlebih baik dari pada kemampuan pemahaman konsep matematis peserta didik dengan perlakuan metode konvensional.

Penelitian ini sama dengan hasil penelitian sebelumnya yaitu model pemebelajaran Example Non Example dan metode Poster Coment dapat meningkatkan tingkat pemahaman konsep siswa serta meningkatkan hasil belajar siswa [9] [14] [16] [18] [19]. Model Example Non Example dapat membantu peserta didik bersikap kritis dalam memecahkan masalah dengan gambar-gambar yang disediakan [13].

\section{SIMPULAN DAN SARAN}

Menurut hasil analisis data dan pengujian hipotesis yang telah dilakukan, maka dapat disimpulkan terdapat pengaruh pada model Example Non Example berbantuan Poster Comment terhadap pemahaman konsep matematis. Selanjutnya pemahaman konsep matematis dengan perlakuan model Example Non Example berbantuan Poster Comment dari pada Selanjutnya pemahaman konsep matematis dengan perlakuan metode konvensional. Berdasarkan simpulan tersebut, maka penulis mamberikan saran sebagai berikut. (1) Lembaga pendidikan khususnya dapat menerapkan model pembelajaran Example Non Example berbantuan metode Poster Coment untuk melatih siswa ikut serta dalam proses pembelajaran dalam meningkatkan kemampuan pemahaman konsep peserta siswa. (2) untuk penelitian yang serupa atau lebih lanjut perlu diobservasikan terlebih dahulu model pembelajaran yang penah diterima oleh siswa sehingga penerapan model pembelajaran Example Non Example berbantuan metode Poster Coment dapat berjalan dengan baik. Semoga apa yang diteliti dapat dilanjutkan oleh penulis lain dengan 
penelitian yang lebih luas. Harapan penulis yang lain adalah apa yang diteliti dapat memberikan manfaat dan sumbangan pemikiran bagi pendidik pada umumnya dan penulis pada khususnya.

\section{DAFTAR PUSTAKA}

[1] F. Farida, "Mengembangkan Kemampuan Pemahaman Konsep Peserta Didik Melalui Pembelajaran Berbasis VCD," Al-Jabar: Jurnal Pendidikan Matematika, vol. 6, no. 1, pp. 25-32, Jun. 2015.

[2] Y. Haryani, "Penggunaan Model Discovery Learning terhadap Peningkatkan Kemampuan Koneksi dan Komunikasi Matematik," Al-Jabar:Jurnal Pendidikan Matematika, vol. 8, no. 1, pp. 43 52, Jun. 2017.

[3] A. Hendrayana, "Pengaruh pembelajaran pendekatan rigorous mathematical thinking (RMT) terhadap pemahaman konseptual matematis siswa SMP," Jurnal Riset Pendidikan Matematika, vol. 4, no. 2, pp. 186-199, Nov. 2017.

[4] H. Agustin, S. Karlinah, A. Abdullah, and D. Supriadi, "Pemetaan kebutuhan kualifikasi jurnalis pemula pada industri media massa di indonesia," Jurnal Kajian Komunikasi, vol. 1, no. 2, pp. 141154, 2013.

[5] S. W. Sudarman and I. Vahlia, "Efektifitas Penggunaan Metode Pembelajaran Quantum Learning terhadap Kemampuan Pemahaman Konsep Matematis Mahasiswa," Al-Jabar: Jurnal Pendidikan Matematika, vol. 7, no. 2, pp. 275-282, Dec. 2016.

[6] N. Netriwati, "Analisis Kemampuan Mahasiswa dalam Pemecahkan Masalah Matematis menurut Teori Polya,” Al-Jabar: Jurnal Pendidikan Matematika, vol. 7, no. 2, pp. 181-190, Dec. 2016.

[7] R. Purwasih, "Peningkatan Kemampuan Pemahaman Matematis dan Self Confidence Siswa MTS di Kota Cimahi Melalui Model Pembelajaran Inkuiri Terbimbing," Didaktik, vol. 9, no. 1, pp. 1625, 2015.

[8] F. Fatqurhohman, "Pemahaman Konsep Matematika Siswa dalam Menyelesaikan Masalah Bangun Datar," JIPM (Jurnal Ilmiah Pendidikan Matematika), vol. 4, no. 2, pp. 127-133, 2016.

[9] I. W. Ningrum and H. Mahfud, "Peningkatan Pemahaman Konsep Sifat-Sifat Bangun Ruang Melalui Metode Examples Non Examples," Jurnal Mahasiswa PGSD, vol. 1, no. 3, 2013.

[10] A. S. Putra, "Penerapan Metode Pembelajaran Example Non Example Pada Mata Pelajaran Pekerjaan Mekanik Dasar Kelistrikan Kelas X Di SMK Negeri 2 Yogyakarta," Skripsi, tidak dipublikasikan. Universitas Negeri Yogyakarta, 2012.

[11] H. Widowati, "Penerapan Pembelajaran Kooperatif Model Examples Non Examples dan STAD Pada Mata Kuliah Struktur Hewan Program Studi Pendidikan Biologi,” BIOEDUKASI Jurnal Pendidikan Biologi), vol. 2, no. 1, 2011.

[12] H. Wijaya and M. Asran, "Pengaruh Model Example Non Example Terhadap Hasil Belajar IPS Kelas V Sekolah Dasar," Jurnal Pendidikan dan Pembelajaran, vol. 2, no. 2, 2013.

[13] C. Mufidah, "Pengaruh Model Pembelajaran Example Non Example Terhadap Pemahaman Konsep Siswa Dan Hasil Belajar Matematika Siswa Kelas VII MTsN Ngantru Tahun AjaraN 2015/2016," 2016.

[14] M. Muliaman, "Penggunaan Metode Poster Comentdalam Pembelajaran Bahasa Indonesia Sebagai Upaya Peningkatan Kemampuan Menulis Murid Kelas VI SD Negeri NO. 47 Joalampe 
Kecamatan Sinjai Selatan Kabupaten Sinjai,” Konfiks: Jurnal Babasa dan Sastra Indonesia, vol. 2, no. 1, pp. 84-91, 2017.

[15] A. Noerjannah, Y. Suryana, and S. Sumardi, "Penerapan Metode Poster Comment Untuk Meningkatkan Berpikir Kreatif Siswa Pada Pembelajaran IPS Di Kelas IV," Pedadidaktika: Jurnal Ilmiah Pendidikan Guru Sekolah Dasar, vol. 3, no. 2, pp. 262-271, 2016.

[16] H. Hermida, "Penggunaan Metode Poster Coment Untuk Meningkatkan Hasil Belajar IPA Materi Perubahan Lingkungan Siswa Kelas IV SD Negeri 012 Koto Kari," GERAM, vol. 5, no. 2, pp. 62-68, 2017.

[17] A. Budiyono, "Advances in unmanned underwater vehicles technologies: Modeling, control and guidance perspectives,” 2009.

[18] A. P. Irawanti, "Keefektifan Model Examples Non Examples Terhadap Hasil Belajar Materi Pengelolaan Sumber Daya Alam Pada Siswa Kelas IV Sekolah Dasar Negeri 1 Toyareka Purbalingga," PhD Thesis, Universitas Negeri Semarang, 2013.

[19] H. Wijaya and M. Asran, "Pengaruh Model Example Non Example Terhadap Hasil Belajar IPS Kelas V Sekolah Dasar," Jurnal Pendidikan dan Pembelajaran, vol. 2, no. 2, 2013. 
Numerical: Jurnal Matematika danPendidikan Matematika, Vol. 2 No. 2 Desember 2018, 139-144

Doni Sabroni, Budi Koestoro, Asmiati

[Halaman ini sengaja dikosongkan] 